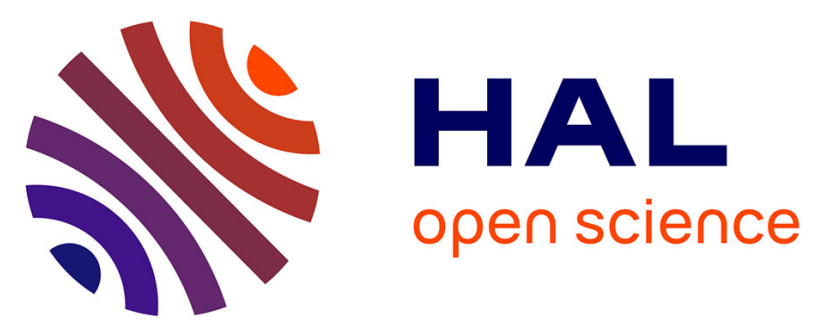

\title{
Octa-arginine-modified pegylated liposomal doxorubicin: An effective treatment strategy for non-small cell lung cancer
}

\author{
Swati Biswas, Pranali P Deshpande, Federico Perche, Namita S Dodwadkar, \\ Shailendra D Sane, Vladimir P Torchilin
}

\section{To cite this version:}

Swati Biswas, Pranali P Deshpande, Federico Perche, Namita S Dodwadkar, Shailendra D Sane, et al.. Octa-arginine-modified pegylated liposomal doxorubicin: An effective treatment strategy for nonsmall cell lung cancer. Cancer Letters, 2013, 335 (1), pp.191 - 200. 10.1016/j.canlet.2013.02.020 . hal-02995795

\section{HAL Id: hal-02995795 \\ https://hal.science/hal-02995795}

Submitted on 9 Dec 2020

HAL is a multi-disciplinary open access archive for the deposit and dissemination of scientific research documents, whether they are published or not. The documents may come from teaching and research institutions in France or abroad, or from public or private research centers.
L'archive ouverte pluridisciplinaire HAL, est destinée au dépôt et à la diffusion de documents scientifiques de niveau recherche, publiés ou non, émanant des établissements d'enseignement et de recherche français ou étrangers, des laboratoires publics ou privés. 


\title{
Octa-Arginine-Modified Pegylated Liposomal Doxorubicin: An Effective Treatment Strategy for Non-Small Cell Lung Cancer
}

\author{
Swati Biswas, Pranali P. Deshpande, Federico Perche, Namita S. Dodwadkar, Shailendra D. \\ Sane, and Vladimir P. Torchilin* \\ Center for Pharmaceutical Biotechnology and Nanomedicine, 360 Huntington Avenue, 140 The \\ Fenway, Northeastern University, Boston, Massachusetts 02115
}

\begin{abstract}
The present study aims to evaluate the efficacy of octa-arginine (R8)-modified PEGylated liposomal doxorubicin (R8-PLD) for the treatment of non-small cell lung cancer, for which the primary treatment modality currently consists of surgery and radiotherapy. Cell-penetrating peptide R8 modification of Doxorubicin-(Dox)-loaded liposomes was performed by post-insertion of an R8-conjugated amphiphilic PEG-PE copolymer (R8-PEG-DOPE) into the liposomal lipid bilayer. In vitro analysis with the non-small cell lung cancer cell line, A549 confirmed the efficient cellular accumulation of Dox, delivered by R8-PLD compared to PLD. It led to the early initiation of apoptosis and a 9-fold higher level of the apoptotic regulator, caspase 3/7 (9.24 \pm 0.34$)$ compared to PLD (1.07 \pm 0.19$)$ at Dox concentration of $100 \mu \mathrm{g} / \mathrm{mL}$. The treatment of A549 monolayers with R8-PLD increased the level of cell death marker lactate dehydrogenase (LDH) secretion $(1.2 \pm 0.1$ for PLD and $2.3 \pm 0.1$ for R8-PLD at Dox concentration of $100 \mu \mathrm{g} / \mathrm{mL})$ confirming higher cytotoxicity of R8-PLD than PLD, which was ineffective under the same treatment regimen (cell viability $90 \pm 6 \%$ in PLD vs. $45 \pm 2 \%$ in R8-PLD after 24 h). R8-PLD had significantly higher penetration into the hypoxic A549 tumor spheroids compared to PLD. R8PLD induced greater level of apoptosis to A549 tumor xenograft and dramatic inhibition of tumor volume and tumor weight reduction. The R8-PLD treated tumor lysate had a elevated caspase3/7 expression than with R8-PLD treatment. This suggested system improved the delivery efficiency of Dox in selected model of cancer which supports the potential usefulness of R8-PLD in cancer treatment, lung cancer in particular.
\end{abstract}

\section{Keywords}

Liposomes; lung cancer; Doxorubicin; Octa-arginine; spheroids; tumor

\footnotetext{
(C) 2013 Elsevier Ireland Ltd. All rights reserved.

*Corresponding author. Vladimir P. Torchilin, Ph.D., D.Sc., Professor and Director, Center for Pharmaceutical Biotechnology and Nanomedicine, Northeastern University, 140 The Fenway (Rm 225), 360 Huntington Ave., Boston, Massachusetts 02115 , v.torchilin@neu.edu, Phone.617-373-3206, Fax.617-373-7509.

Publisher's Disclaimer: This is a PDF file of an unedited manuscript that has been accepted for publication. As a service to our customers we are providing this early version of the manuscript. The manuscript will undergo copyediting, typesetting, and review of the resulting proof before it is published in its final citable form. Please note that during the production process errors may be discovered which could affect the content, and all legal disclaimers that apply to the journal pertain.

Conflict of Interest Statement

None
} 


\section{Introduction}

Lung carcinoma is the most frequent cancer in the world, with an incidence of 1.5 million new cases per year, accounting for approximately one-third of all cancer-related deaths [1; 2]. Non-small cell lung cancer (NSCLC) is prevalent ( $85 \%$ ) among all lung cancer types. $65-80 \%$ of all lung cancer patients are diagnosed at an advanced stage of local carcinoma or metastasis [3; 4]. Surgery remains the most successful treatment option for patients with early detection of the disease [1]. However, the rate of recurrence is $90 \%$ in the first five years after surgery $[2 ; 5 ; 6]$. There is only a $5 \%$ absolute benefit of adding chemotherapy to surgery, a minimal gain in overall patient survival rates $[7 ; 8 ; 9 ; 10 ; 11]$. Another chemotherapy-related problem is that the relapsed tumors acquire resistance to the administered chemotherapy. Therefore, there is a significant unmet need for developing more effective treatment regimens for NSCLC.

The platinum containing drugs, cisplatin and carboplatin are considered the first choice of chemotherapy for NSCLC [12]. Paclitaxel or docetaxel in combination with either of the two platinum drugs is used as a second-line treatment [13;14]. Doxorubicin, alone, or in combination, are currently in clinical trials for advanced stages of NSCLC [15; 16; 17]. However, treatment with Dox is associated with numerous side-effects including severe cardiotoxicity $[18 ; 19]$.

The use of liposomes has advantages in cancer treatment due to their enhanced permeability and retention related to their small size $(\sim 100 \mathrm{~nm})$ that allows passage through leaky tumor blood vessels and accumulation preferentially in the tumor [20; 21]. In this regard, liposomes need to be modified to impart the property of long systemic circulation that leads to eventual accumulation in the tumor. Nonetheless, the nano carrier's drug load has to be released at the tumor site, has to be efficiently cellular-internalized and followed by release from endosomes to demonstrate drug efficacy [22]. For long circulation, liposomes are coated with hydrophilic polymers, mainly polyethylene glycol (PEG). However, the PEGmodified liposomes leads to reduced cellular internalization.

Long-circulating pegylated liposomal Doxorubicin (commercially available as Doxil ${ }^{\circ}$ or Lipodox $($ ) is an example of a "stealth" liposome, an indispensible treatment means for metastatic, breast and ovarian cancers [23]. Doxilß represents an improved formulation of free drug with better pharmacokinetic profile and reduced cardiotoxicity. However, its therapeutic efficacy is not dramatically increased and adverse side-effects remain, indicating a further improvement of this formulation. Addressing the issue of poor cellular internalization is one of the approaches used to improve the therapeutic window of the drug.

Intracellular or organelle-specific targeting is an emerging concept for improvement of drug action of the nanocarriers $[22 ; 24 ; 25 ; 26]$. Since the nanocarriers utilize energy-dependent endocytosis as a major pathway for cellular internalization rather than random diffusion typical for small drug molecules, a cell penetration enhancer would dramatically improve their cytoplasmic delivery $[27 ; 28 ; 29 ; 30]$. In this regard, many peptide sequences have been identified that cause translocation of a variety of cargos across the cell membrane [28]. Poly-arginine, a relatively short cell-penetrating peptide, with an optimum chain length of 8arginine units has been successfully utilized for intracellular delivery of therapeutics [31;32; 33; 34]. A possible internalization pathway of the R8-modified liposomes has also been investigated [35].

In this study, we have utilized R8 modified liposomes to enhance the penetration of lung cancer cells. R8-conjugated amphiphilic poly(ethylene glycol)-dioleoyl phosphatidylethanolamine (PEG-DOPE) conjugate, R8-PEG-DOPE was incorporated in the lipid bilayer of PLD. PEG-DOPE copolymer is much used for liposomes modification due 
to its biocompatibility and non-immunogenicity [20]. The hydrophobic lipid moiety in the conjugate could be easily embedded in the liposomal bilayer to allow surface modifications. The PEG-spacer imparts easy R8-accessibility for the cell surface interaction. The therapeutic efficacy of R8-modified Pegylated liposomal Doxorubicin (PLD) was assessed in human alveolar adenocarcinoma cell line to evaluate the potential benefit of R8-PLD in the debilitating NSCLC treatment.

\section{Materials and methods}

\subsection{Materials}

Octa-arginine peptide (R8, MW. 1267.46 Da) was synthesized by the Tufts University Core Facility (Boston, MA). Pegylated Liposomal Doxorubicin (Lipodox ${ }^{\circledR}, 2 \mathrm{mg} / \mathrm{mL}$ of Dox) was purchased from Sun Pharmaceutical India Ltd (Gujarat, India). 1,2-distearoyl-snglycero-3-phosphoethanolamine-N-[methoxy(polyethylene glycol)-2000](ammonium salt) (PEG-2K-DOPE), 1,2-Dioleoyl-sn-glycero-3-phosphoethanolamine (DOPE) was purchased from Avanti Polar Lipids (AL, USA). NPC-PEG- $2 \mathrm{~K}^{-\mathrm{NPC}}$ was purchased from Laysan Bio (AL, USA). thiazoyl blue tetrazolium bromide (MTT) was purchased from Sigma-Aldrich (St. Louis, MO). Micro BCA protein assay kit, Apo-ONE® Homogeneous Caspase-3/7 Assay and CytoTox 96 Non-Radioactive Cytotoxicity Assay kits were purchased from Promega (Madison, WI). Annexin V Alexa Fluor ${ }^{\circledR} 488$ conjugate, Annexin-binding buffer 5X concentrate and Hoechst 33342 were purchased from Molecular Probes Inc. (Eugene, OR). Para-formaldehyde was from Electron Microscopy Sciences (Hatfield, PA). Fluoromount-G was from Southern Biotech (Birmingham, AL). The Trypan blue solution was obtained from Hyclone (Logan, UT).

\subsection{Cell lines}

The human alveolar adenocarcinoma cell line, A549 was purchased from the American Type Culture Collection (Manasas, VA). Dulbecco's modified Eagle's media (DMEM) and heat-inactivated fetal bovine serum (FBS) were obtained from Gibco (Carlsbad, CA). Concentrated penicillin/streptomycin stock solution was from CellGro® (Herndon, VA). All other chemical and solvents were of analytical grade, purchased from Sigma-Aldrich and used without further purifications. A549 cells were grown in DMEM with $2 \mathrm{mM} \mathrm{L-}$ glutamine, supplemented with $10 \%$ (v/v) heat-inactivated fetal bovine serum, 100 units $/ \mathrm{mL}$ penicillin $\mathrm{G}$ and $100 \mu \mathrm{g} / \mathrm{mL}$ streptomycin. Cultures were maintained in a humidified atmosphere at $37{ }^{\circ} \mathrm{C}$ and $5 \% \mathrm{CO}_{2}$.

\subsection{Synthesis of R8-PEG-2K-DOPE}

For this purpose, $\mathrm{pNP}^{\mathrm{PEG}} \mathrm{F}_{2}$-DOPE was synthesized and purified according to an established procedure with modification $[24 ; 36]$. Briefly, into the solution of NPC-PEG $\mathrm{PK}^{-}$ NPC $(1 \mathrm{~g}, 0.5 \mathrm{mmol})$ in chloroform, a DOPE $(37.2 \mathrm{mg}, 0.05 \mathrm{mmol})$ solution in chloroform mixed with $20 \mu \mathrm{L}$ of triethylamine was added drop wise. The reaction mixture was stirred overnight at room temperature. On the following day, the reaction mixture was evaporated using a rotary evaporator and freeze-dried to remove traces of solvent. The dry, crude reaction mixture was dissolved in $\mathrm{HCl}$ solution $(0.01 \mathrm{M})$ and purified by gel filtration chromatography using a $\mathrm{Cl}_{4} \mathrm{~B}$ column. A $\mathrm{HCl}$ solution was used as an eluent. The pure fractions were freeze-dried, weighed and dissolved in chloroform to obtain a $10 \mathrm{mg} / \mathrm{mL}$ solution for storage at $-80{ }^{\circ} \mathrm{C}$. For the synthesis of R8-PEG $\mathrm{P}_{2}-\mathrm{DOPE}$, into a solution of pNP-PEG ${ }_{2 \mathrm{~K}}$-DOPE $(10 \mathrm{mg}, 3.9 \mu \mathrm{mol})$ in chloroform $(1.0 \mathrm{~mL})$, R8 $(7.4 \mathrm{mg}, 5.86 \mu \mathrm{mol})$ and triethylamine $(10 \mu \mathrm{L})$ dissolved in DMF $(200 \mu \mathrm{L})$ was added. The reaction mixture was stirred overnight at room temperature. The chloroform was evaporated by rotary evaporation and freeze-dried. The dry reaction mixture was dissolved in PBS, pH 8.4 and stirred at room temperature for $4 \mathrm{~h}$ and dialyzed against water using a cellulose ester membrane (MWCO. 
$2000 \mathrm{Da}$ ) overnight. The dialysate was freeze-dried to obtain a solid white fluffy product which was dissolved in methanol at $5 \mathrm{mg} / \mathrm{mL}$ and stored at $-80^{\circ} \mathrm{C}$.

\subsection{Modification of liposomes}

Using the post-insertion method, [37; 38; 39] we decorated Lipodox ${ }^{\circledR}$ with R8-PEG $\mathrm{K}^{-}$ DOPE conjugate. The inserted conjugate was 2 mol \% of the total lipids. Briefly, Lipodox ${ }^{\circledR}$ $(1.0 \mathrm{~mL})$ was added into the dry lipid film of $\mathrm{PEG}_{2 \mathrm{~K}}$-DSPE $(0.90 \mathrm{mg}, 0.45 \mu \mathrm{mol})$ or R8$\mathrm{PEG}_{2 \mathrm{~K}}$-DOPE $(1.64 \mathrm{mg}, 0.45 \mu \mathrm{mol})$. The liposomal suspension, PLD and R8-PLD were vortexed for complete hydration of the lipid film and stirred overnight at $4{ }^{\circ} \mathrm{C}$.

\subsection{Characterization of liposomes}

Surface-modified liposomes (PLD and R8-PLD) were analyzed for size and zeta-potential. The liposomal size and size distribution was measured by dynamic light scattering (DLS) using a Coulter® N4-Plus Submicron Particle Sizer (Coulter Corporation, Miami, FL). Liposome surface charge was measured using a Zeta Phase Analysis Light Scattering (PALS) Ultrasensitive Zeta Potential Analyzer instrument (Brookhaven Instruments, Holtsville, NY).

\subsection{Cell association of liposomes}

Cell association of liposomes was assessed by FACS analysis. After the initial passage in $\mathrm{T}-75 \mathrm{~cm}^{2}$ tissue culture flasks (Corning Inc., NY), A549 cells $\left(0.4 \times 10^{6} /\right.$ well) were seeded in 6-well tissue culture plates. The following day, the cells were incubated with PLD or R8PLD at a Dox concentration of $6 \mu \mathrm{g} / \mathrm{mL}$ in $2 \mathrm{~mL}$ of serum-free media for $1 \mathrm{~h}$ and $4 \mathrm{~h}$ incubation periods. The media were removed, the cells washed several times, trypsinized, suspended in $1 \mathrm{~mL}$ PBS and then centrifuged at $1000 \mathrm{RPM}$ for $5 \mathrm{~min}$. The cell pellet was suspended in PBS, pH 7.4 before analysis of the cells labeled with Dox fluorescence using a BD FACS Caliber flow cytometer. The cells were gated using forward (FSC-H)-versus sidescatter (SSC-H) to exclude debris and dead cells before analysis of 10,000 cell counts.

\subsection{Cellular internalization of liposomes}

Cellular uptake of liposomes was analyzed by visualization with confocal microscopy. After the initial passage in tissue culture flasks, A549 cells $\left(4 \times 10^{4}\right)$ were grown on circular cover glasses placed in 12-well tissue culture plates in complete media. The following day, cells were incubated with PLD or R8-PLD at a Dox concentration of $6 \mu \mathrm{g} / \mathrm{mL}$ for $1.5 \mathrm{~h}$ in serumfree media. After the incubation period, the cells on the cover-slips were washed 4 times with PBS, treated with Hoechst 33342 at $5 \mu \mathrm{g} / \mathrm{mL}$ for $5 \mathrm{~min}$, washed thoroughly and fixed with $4 \%$ para-formaldehyde for $10 \mathrm{~min}$ at room temperature. The cover-slips were again washed with PBS and mounted cell-side down on superfrost microscope slides with fluorescence-free glycerol-based mounting medium (Fluoromount-G) and viewed with a Zeiss LSM 700 Confocal Laser Scanning Microscope equipped with UV (ex/em. 385/470 $\mathrm{nm}$ ) and rhodamine filter (ex/em. 548/719 nm) for imaging. The z-stacked images (Z 1-15, slice thickness, $0.75 \mu \mathrm{m}$ ) were obtained by capturing serial images of the $\mathrm{x}-\mathrm{y}$ planes by varying the focal length of the same to image along consecutive z-axes. The LSM picture files were analyzed using Image $J$ software. Nuclear localization of the Dox signal delivered by PLD or R8-PLD was assessed by determining Pearson's and Mander's coefficients of colocalization using Image $J$ software.

\subsection{Formation of spheroids}

Spheroids of 800-900 $\mu \mathrm{m}$ diameter were formed from 10,000 A549 cells in 96-well plates according to Yang et al. with modifications as follows [40; 41]. A549 cells were maintained as monolayers before detachment with trypsin to generate a single-cell suspension. Then, 
10,000 cells in $100 \mu \mathrm{L}$ of media were added to each well of a 96 well plate previously coated with $50 \mu \mathrm{L}$ of DMEM $1.5 \%$ agarose. Finally, the plates were centrifuged $15 \mathrm{~min}$ at 1,500 rcf to form spherical cell mass which was incubated for approximately 4 days with no medium change. Spheroid formation was monitored using a Nikon Eclipse E400 microscope at $10 \mathrm{X}$ magnification and with a Spot Insight 3.2.0 camera with Spot Advanced software (Spot Imaging). Spheroids of 800-900 $\mu \mathrm{m}$ size were used for experiment.

\subsection{Liposomal penetration of spheroids}

Spheroids were incubated with PLD and R8-PLD at a Dox concentration of $100 \mu \mathrm{M}$ for $1 \mathrm{~h}$ or $4 \mathrm{~h}$, washed with PBS and viewed with a Zeiss LSM 700 Confocal Laser Scanning Microscope equipped with rhodamine filter (ex/em. 548/719 nm) using a 10X objective. The $Z$-stacked images of spheroids (z 1-16) were obtained by capturing serial images of the $\mathrm{x}-\mathrm{y}$ planes by varying the focal length to image along consecutive z-axis. The LSM picture files of spheroids were analyzed for quantifying the mean intensity using Image $J$ software.

\subsection{Annexin V assay}

The procedure for Annexin V labeling was carried out according to the manufacturer's protocol. A549 cells were seeded in 12 -well plates at $8 \times 10^{4} /$ well. After incubation of A549 cells for $4 \mathrm{~h}$ with PLD or R8-PLD at a Dox concentration of $15 \mu \mathrm{g} / \mathrm{mL}$, the cells were incubated for an additional $18 \mathrm{~h}$, trypsinized, washed with cold binding buffer, and resuspended in Annexin V-Alexa Fluor 488 conjugate $(15 \mu \mathrm{L})$-added binding buffer $(200 \mu \mathrm{L})$ for $15 \mathrm{~min}$ in darkness. The cells were diluted with binding buffer at total volume $400 \mu \mathrm{L}$ and analyzed immediately by flow cytometry.

\subsection{Cytotoxicity studies}

MTT assay-For cytotoxicity assays including MTT, LDH release and caspase assay, A549 cells were seeded into 96 well microplates at a density of $5 \times 10^{3}$ and $3 \times 10^{3}$ cells/well for 24 and $48 \mathrm{~h}$ respectively in phenol red-free DMEM media. On the following day, the cells were incubated with PLD or R8-PLD at Dox concentrations of $0-100 \mu \mathrm{g} / \mathrm{mL}$ for $4 \mathrm{~h}$. Media was removed and the cells were incubated for an additional 24 and $48 \mathrm{~h}$ in fresh complete media. After the incubation period, the media was removed and the cells were treated with 3-(4,5-Dimethylthiazol-2-yl)-2,5-diphenyl-2H-tetrazolium bromide (MTT) solution $(5 \mathrm{mg} / \mathrm{mL})$ in serum-free DMEM for $4 \mathrm{~h}$. At the end of the incubation period, cell viability was estimated by the ability of the cells to reduce the yellow dye, MTT to a purple formazan product. The media was replaced with $100 \mu \mathrm{L}$ of SDS solution $(20 \%)$ in $0.01 \mathrm{~N}$ $\mathrm{HCl}$ for $4 \mathrm{~h}$ to dissolve the formazan crystals. The absorbance was read at $570 \mathrm{~nm}$ using a microplate reader (Synergy HT multimode microplate reader, Biotek Instrument, Winooski, VT). Blank readings obtained from the treatment well with no cells were subtracted from each reading.

LDH release-The A549 cells were treated with PLD or R8-PLD at a Dox concentration range of $0-100 \mu \mathrm{g} / \mathrm{mL}$ for $4 \mathrm{~h}$ followed by removal of the media and further incubation for 24 and $48 \mathrm{~h}$. Released lactate dehydrogenase (LDH) in the media was measured with a Cytotox 96 Non-Radioactive Cytotoxicity Kit (Promega) following manufacturer's instruction. LDH release was normalized to total LDH content following cell lysis with a medium containing $0.9 \%$ Triton X-100. The plate was read with a Multi-mode microplate reader (Synergy HT; Biotek; absorbance. $340 \mathrm{~nm}$ ).

Caspase assay-After the treatment of A549 cells with PLD or R8-PLD at Dox concentration range of $0-200 \mu \mathrm{g} / \mathrm{mL}$ for $4 \mathrm{~h}$ and incubating the cells for additional 24 and 48 $\mathrm{h}$ in phenol red-free complete medium, the samples were analyzed using the Apo-ONE 
Homogeneous Caspase 3/7 Assay (Promega) following manufacturer's instructions. Briefly, following the incubation period, caspase substrate was diluted in Apo-ONE Homogeneous Caspase-3/7 Buffer and $100 \mu \mathrm{L}$ added to cells in $100 \mu \mathrm{L}$ media and kept at room temperature with additional gentle shaking. The plates were read after $4 \mathrm{~h}$ using the microplate reader at ex/em. $499 / 521 \mathrm{~nm}$. The values were directly proportional to the amount of apoptotic induction. A blank (all reagents without cells) reading was subtracted from each reading.

For the determination of caspase 3/7 level in the A549 tumor xenograft, tumors were lysed using a hand-held tissue homogenizer (Qiagen, CA, USA) in PBS, pH 7.4 at $0{ }^{\circ} \mathrm{C}$ and protein content was measured using micro BCA protein assay using manufacturer's protocol. $25 \mu \mathrm{g}$ of protein in $100 \mu \mathrm{L}$ (PBS, pH 7.4) was added to wells of a 96-well plate. Samples were analyzed immediately as above.

\subsection{Animals}

Immunodeficient NU/NU nude mice (4-6 weeks old) were purchased from Charles River Laboratories, MA, USA. All animal procedures were performed according to an animal care protocol approved by Northeastern University Institutional Animal Care and Use Committee. Mice were housed in groups of 5 at $19-23{ }^{\circ} \mathrm{C}$ with a $12 \mathrm{~h}$ light-dark cycle and allowed free access to food and water.

\subsection{In vivo tumor xenograft}

A subcutaneous tumor was initiated by inoculating A549 human alveolar adenocarcinoma cells $\left(2 \times 10^{6}\right.$ suspended in $100 \mu \mathrm{L}$ PBS $)$ over the left flank. The time for the appearance of the tumor was usually 7 days. However, after an initial phase of slow growth, tumors increased grow and reached a volume of $400 \mathrm{~mm}^{3}$ after 60 days from implantation. The length and width of the tumor was measured by calipers at 3 days interval and the tumor volume was calculated using the formula: (width ${ }^{2} \times$ length) $/ 2$. Treatment was started when the tumors reached a size of $400 \mathrm{~mm}^{3}$.

\subsection{Assessment of tumor volume reduction and TUNEL assay}

To measure the pro-apoptotic effect following PLD or R8-PLD treatment, the TUNEL assay was performed on the frozen tumor sections. Mice ( $\mathrm{n}=3$ in each group) bearing tumor of $\sim 400 \mathrm{~mm}^{3}$ volume were injected twice with PLD or R8-PLD at a Dox dose of 2 and $10 \mathrm{mg}$ / $\mathrm{Kg}$ at day 1 and 3 respectively. The tumor volume was measured on days 1, 3, and 6 . The animals were euthanized with $\mathrm{CO}_{2}$ on day 6 and the tumors were isolated. The tumors were washed quickly with PBS, $\mathrm{pH} 7.4$, weighed and frozen immediately after the extraction by immersing in tissue freezing media and stored at $-80^{\circ} \mathrm{C}$. Tumor slices $(8 \mu \mathrm{m})$ were cryosectioned using Cryotome Cryostat, mounted on superfrost plus slides, fixed in $4 \%$ paraformaldehyde for $10 \mathrm{~min}$ at RT, permeabilized with proteinase $\mathrm{K}(20 \mu \mathrm{g} / \mathrm{mL})$ for $15 \mathrm{~min}$ at RT. A TUNEL assay was performed on the sections using the FragEl ${ }^{T M}$ DNA fragmentation detection Kit following manufacturer's instructions for frozen sections. The TUNEL positive cells were detected by fluorescence microscopy equipped with a FITCfilter. Four random images obtained from two different tumors for each treatment group were analyzed using Spot advanced software.

\subsection{Statistical analysis}

The data were tested for statistical significance using Student's t-tests. $p$ values, calculated with the Graph Pad prism 5 software (GraphPad Software, Inc, San Diego, CA). All numerical data are expressed as mean $\pm \mathrm{SD}, \mathrm{n}=3$ or 4 , from 3 different experiments. Any $p$ values less than 0.05 was considered statistically significant. $* * *, * * *$ in figures indicated $p$ values $<0.05,0.01$ and 0.001 , respectively. 


\section{Results}

\subsection{Physico-chemical characterization of liposomes}

The particle size of PLD and R8-PLD was $84.5 \pm 10.9 \mathrm{~nm}$ and $90.5 \pm 27.6 \mathrm{~nm}$ respectively. R8-PLD demonstrated an increased zeta potential of $-11.34 \pm 3.87 \mathrm{mV}$ compared to PLD with zeta value of $-47.53 \pm 3.82 \mathrm{mV}$.

\subsection{Cell association of liposomes}

The cell association of liposomes were quantified by detecting cell associated Dox fluorescence using FACS analysis. R8-modification on the liposomal surface increased the cellular association compared to unmodified liposomes (Figure 1). The geometric mean of fluorescence indicating cell association, was significantly higher for R8-PLD at both tested time points. A representative dot plot in Figure 1A shows the shift of the labeled cell population fluorescence compared to untreated cells. The mean cellular fluorescence at $1 \mathrm{~h}$ R8-PLD treatment was $11.46 \pm 0.33$ and increased to $15.5 \pm 0.30$ at $4 \mathrm{~h}$ whereas the fluorescence values for PLD were 9.21 \pm 0.17 and $10.67 \pm 1.95$, respectively (Figure 1B).

\subsection{Cellular Internalization of liposomes}

Confocal laser scanning micrographs of PLD and R8-PLD-treated cells at a fixed X-Y plain with varied Z-axis are shown in Figure 2A. The micrographs of center slices (Z7-Z9) showed higher cellular internalization of Dox in R8-PLD compared to PLD. Localization of the Dox signal to the nucleus was observed in the merged pictures as indicated by purple signal, whereas most of the Dox signal delivered via PLD was in the cytosolic compartment. The averaged Pearson's and Mander's coefficients obtained by the Image $J$ analysis of the three center $\mathrm{z}$-stacked images were $0.40 \pm 0.10,0.49 \pm 0.03$ for PLD and $0.71 \pm 0.04,0.9 \pm$ 0.11 , respectively (Figure 2B)

\subsection{Accumulation of liposomes in spheroids}

Spheroids are a robust model to study the tumor penetration behavior of drugs/drug delivery systems in cancer since spheroids to a great extent mimic both the architecture of tumors and the penetration barriers of solid tumors where drugs are mostly confined to the outer cell layers. The Z-stacked images of spheroids showed higher accumulation of R8-PLD compared to PLD at both the time points (Figure 3). The formulations had limited penetration in $1 \mathrm{~h}$. However, R8-PLD demonstrated very high accumulation in the center zone of the spheroids at $4 \mathrm{~h}$, as shown by the center slice (100 $\mu \mathrm{m}$ from top). Mean intensity (arbitrary units) of the Dox signal in the center slice of the PLD and R8-PLD treated spheroids, quantified by Image $\mathrm{J}$ analysis was $29.7 \pm 1.2,71.7 \pm 1.5$ for $1 \mathrm{~h}$ and $105 \pm 5$, $178.6 \pm 3.2$ for $4 \mathrm{~h}$, respectively.

\subsection{Assessment of early apoptosis}

Binding of the fluorescently labeled Annexin V to the cell surface-bound early apoptotic marker, phosphatidyl serine is used to detect early apoptosis. Initiation of apoptosis causes translocation of phosphatidyl serine from inner cytoplasmic membrane to the outer surface. The FACS analysis result demonstrating the comparison of up-regulation of this early apoptotic marker upon treatment with PLD and R8-PLD has been illustrated in Figure 4. After treatment, both PLD and R8-PLD initiated apoptosis, demonstrating a shift in the cell population as shown by the increased labeling of the cells with the Annexin V-Alexa Fluor-488 conjugate. However, R8-PLD treated cells had significantly higher total geometric mean fluorescence $(182.67 \pm 10.8)$ compared to PLD treated cells $(129.80 \pm$ 5.36). The lower right quadrant was additionally gated to analyze the phosphatidyl serine 
expression, $8.7 \pm 1.5 \%$ of the cell population was there for R8-PLD compared to $3.6 \pm 0.5$ $\%$ for PLD.

\subsection{Assessment of cell viability by MTT assay}

To determine whether the initiation of apoptosis leads to decreased cell viability, an MTT assay was performed (Figure 5). A statistically significant decrease in cell viability was observed with R8-PLD treatment compared to PLD at Dox concentration of $6.25 \mu \mathrm{g} / \mathrm{mL}$ and greater. R8-PLD treatment showed a $\sim 55 \%$ decrease in cell viability compared to $\sim 10 \%$ with PLD at the highest used Dox concentration of $100 \mu \mathrm{g} / \mathrm{mL}$ (\% cell viability for R8-PLD treatment was $45.35 \pm 2.14 \%$, compared to $89.6 \pm 5.9 \%$ for PLD at $100 \mu \mathrm{g} / \mathrm{mL}$ of Dox concentration). Slow decrease in the cell viability $(62.89 \pm 1.95 \%$ to $45.35 \pm 2.14 \%$ at $24 \mathrm{~h}$ and $53.5 \pm 5.71 \%$ to $46.10 \pm 2.56 \%$ at $48 \mathrm{~h}$ ) was observed with R8-PLD treatment at Dox concentration between 6.25 and $100 \mu \mathrm{g} / \mathrm{mL}$.

\subsection{Assessment of other cell death markers}

Release of lactate dehydrogenase (LDH) in the media by apoptotic/necrotic cells and upregulation of apoptotic protein, caspase 3/7 in the cells were quantified (Figure 6). The R8PLD-treated cells had significantly higher level of LDH release compared to PLD at all tested Dox concentrations. There was a Dox-concentration dependent increase in LDH release in R8-PLD-treated cells. No noticeable increase in LDH release was observed in PLD treatment even at highest Dox concentration of $100 \mu \mathrm{g} / \mathrm{mL}$ (Figure 6A). There was 1.9fold increase in the level of LDH release in R8-PLD compared to PLD at Dox concentration of $100 \mu \mathrm{g} / \mathrm{mL}$. Figure 6B illustrates caspase 3/7 activity after PLD and R8-PLD treatment. At a Dox concentration of $200 \mu \mathrm{g} / \mathrm{mL}$, the R8-PLD treatment increased caspase 3/7 level 5.5-fold compared to PLD treatment ( $13.72 \pm 0.15$ for R8-PLD vs. $2.48 \pm 0.54$ for PLD). Likewise, a LDH release profile of the Dox concentration-dependent increase in the caspase 3/7 protein level was observed in R8-PLD.

\subsection{Assessment of in vivo therapeutic efficacy}

The tumor volumes and weights of post-mortem tumors were measured. The initial tumor volume at day 1 was $397.4 \pm 5.9,405.0 \pm 3.5,397.8 \pm 4.7 \mathrm{~mm}^{3}$ which was increased at day 3 to $496.38 \pm 10.5,475.70 \pm 15.2$ and $451.25 \pm 8.2 \mathrm{~mm}^{3}$ for PBS, PLD and R8-PLD treated mice, respectively. On the day of euthanize (day 6), strong suppression of tumor volume was observed with R8-PLD treatment. On day 6, the tumor volumes reached to 674.16 \pm 20.5 , $600.00 \pm 25.0,368.56 \pm 18.5 \mathrm{~mm}^{3}$ for PBS, PLD and R8-PLD treatment, respectively. The tumor weight after isolation was $0.5802 \pm 0.20,0.5561 \pm 0.1$ and $0.355 \pm 0.05 \mathrm{~g}$ for PBS, PLD and R8-PLD treatment, respectively. Detection of apoptotic cells by TUNEL assay, the measurement of the level of caspase 3/7 in PLD, R8-PLD or PBS-treated solid A549 tumors were detected. in the apoptotic cells in tumor sections by TUNEL staining. The cell-nuclei of tumors treated with PBS or PLD treatment exhibited no green fluorescence attributable to FITC-labeled TdT, while the tumors treated with R8-PLD had significantly higher amounts of green dots representative of apoptotic nuclei (Figure 7). The level of caspase 3/7 expression in R8-PLD-treated tumor lysate was significantly higher (1.1 fold) compared to PBS and PLD treatment. Thus, R8-modified PLD allowed for a strong pro-apoptotic effect of Dox in an in vivo mouse A549 tumor xenograft model.

\section{Discussion}

Determining an effective treatment strategy for cancer including NSCLC is challenging as among all the patients with lung cancer, $55 \%$ are diagnosed at an advanced stage. Surgery, radiotherapy and chemotherapy are being utilized as treatment options for lung cancer with high chances of relapse [42]. Platinum-based chemotherapy is the first-line chemotherapy 
for NSCLC patients. Other cytotoxic agents such as docetaxel, pemetrexed, gefetinib are options for second or third-line therapy. However, the high incidence of relapsed tumor growth necessitates work on development of an effective chemotherapeutic treatment regimen [4]. Dox, combined with platinum-based therapy or radiotherapy is currently in clinical trials for locally advanced NSCLC.[ 43; 44; 45] Dox is one of the most effective anticancer drugs ever developed and considered a first-line chemotherapeutic [46]. However, Dox, like other chemotherapeutic drugs, has many adverse effects, the most debilitating is cumulative dose-dependant cardiotoxicity.[ 18; 19] Pegylated liposomal Doxorubicin (PLD) (commercially available as Doxil@, Lipodox $®$ ), is a nano-sized Doxloaded carrier, which accumulates specifically in tumor sites by the enhanced permeability and retention effect, reduces the toxicity of free Dox $[20 ; 21 ; 23 ; 47 ; 48]$. Coating of liposomes with biocompatible, non-immunogenic polymer PEG imparts non-recognition by plasma serum opsonins that renders prolonged plasma circulation, which is advantageous for tumor targeted nanocarrier accumulation via EPR effect. However, PEGylation hinders intracellular delivery in the cancer cells after accumulation at the tumor site and the maximum therapeutic benefit of Dox is not achieved. This necessitates further modification of PLD for cytosolic delivery to improve the effectiveness of this highly potent anticancer drug.

In an attempt to promote cellular internalization, we surface-modified PLD with the cellpenetrating octa-arginine (R8) peptide. The relatively short, synthetic R8 peptide resembles the peptide sequence of HIV-1TAT peptide. This highly charged basic peptide has demonstrated efficient cell transport properties [31; 32; 34; 35]. The R8-conjugated amphiphilic PEG-DOPE co-polymer was successfully inserted into the liposome's lipid bilayer. This modification of the surface of PLD with a cationic peptide increased the positive charge on the surface of R8-PLD compared to PLD. However, the size remained unchanged. As expected, R8-PLD had a time-dependent higher cell association compared to PLD, as estimated by tracking the cell associated Dox fluorescence. The cellular internalization, PLD- and R8-PLD-treated cells visualized under confocal microscopy using z-stacked imaging indicate that R8-PLD had a higher cytosolic Dox delivery compared to PLD and indicated the co-localization of Dox at its nuclear site of action. Higher colocalization coefficients (Pearson's and Mander's) in R8-PLD treated cells obtained by Image $J$ analysis of the center slices clearly pointed out the higher intracellular Dox-delivery efficiency of R8-PLD compared to PLD. Even though, R8 has been recognized as a cell penetration enhancer in previous studies, however, the intracellular trafficking of R8 after cellular internalization remain relatively unexplored. While investigating intracellular trafficking of D, and L-enantiomer of R8, Fretz et al reported that D-R8 was additionally bound to the nucleolus, whereas both of them translocated in the cytoplasm and labeled nucleus [49]. Therefore, the enhanced Dox delivery to the nucleus by R8-PLD compared to PLD could be due to enhanced intracellular delivery coupled with R8-mediated nuclear targeting. However, the role of R8 as a promoter for nuclear delivery needs detailed investigation.

Over the past several years, spheroids, a 3D multilayer, sphered cell culture system has garnered much attention as an important tool to study several drug developmental stages including drug transport, binding, therapy resistance as well as cell invasion in cancer.[ 41 ; $50 ; 51 ; 52 ; 53]$ Spheroids supplement monolayer-based assays as they better mimic the complexities of the tumor tissues. The multicellular spheroids resemble avascular tumor modules of solid tumors, the cells in spheroids resorting to an in vivo-like differentiation pattern due to the resemblance in pathophysiological milieu conditions such as extracellular matrix assembly as well as cell-matrix and cell-cell interactions [50]. Due to similarities of spheroids with in vivo tumor tissues, spheroids have been considered as an inevitable tool to utilize in the therapeutic development before turning to whole animal studies $[50 ; 51 ; 54$; 
55; 56]. We studied liposomal accumulation in spheroids and demonstrated that R8-PLD had allowed for much higher Dox penetration compared to PLD as follows from the enhanced Dox signal in the center slices of the z-stacked images (Figure 3). The higher cellular uptake of R8-PLD led to higher apoptosis mediated by Dox compared to PLD. The result demonstrated that the R8-PLD treated cells have higher expression of the protein phosphatidyl serine compared to PLD. The resultant induction of early apoptosis was consistent with higher cytotoxicity. The result demonstrated that R8-PLD induced higher Dox-mediated cytotoxicity compared to PLD. The induction of apoptosis is indicated by the elevated release of cell death marker LDH and the up-regulation of the pro-apoptotic protein, caspase 3/7. R8-PLD demonstrated higher release of LDH and up-regulation of caspase 3/7 in A549 monolayer compared to PLD. The in vivo experiment using A549 tumor xenograft demonstrated that R8-PLD significantly reduces the tumor growth compared to the PLD treatment. Higher induction of apoptosis by R8-PLD treatment was demonstrated by TUNEL assay compared to PLD. Tumor lysate of R8-PLD treated A549 tumor bearing mice had increased caspase 3/7 expression compared to PLD treatment due to the higher intracellular Dox delivery achieved by R8-PLD over PLD.

In conclusion, this study has identified a novel liposomal drug delivery system, R8-modified PLD, for improved chemotherapy of NSCLC. R8-PLD addresses the issue of poor cell penetration by PLD to increase its therapeutic efficacy. The study provides a rationale for the continued invEstigation of R8-PLD as a promising anti cancer therapy.

\section{Acknowledgments}

The work was supported in part by NIH grants RO1 CA121838 and RO1 CA128486 to Vladimir P. Torchilin. We thank Dr. William Hartner for his help in editing the manuscript.

\section{References}

1. Le Chevalier T. Non-small cell lung cancer: the challenges of the next decade. Front Oncol. 2011; 1:29. [PubMed: 22649759]

2. Lopez-Gonzalez A, Ibeas Millan P, Cantos B, Provencio M. Surveillance of resected non-small cell lung cancer. Clin Transl Oncol. 2012

3. Novello S, Le Chevalier T. Chemotherapy for non-small-cell lung cancer. Part 1: Early-stage disease. Oncology (Williston Park). 2003; 17:357-364. [PubMed: 12661267]

4. Nagano T, Kim YH, Goto K, Kubota K, Ohmatsu H, Niho S, Yoh K, Naito Y, Saijo N, Nishiwaki Y. Re-challenge chemotherapy for relapsed non-small-cell lung cancer. Lung Cancer. 2010; 69:315-318. [PubMed: 20071052]

5. Mountain CF. A new international staging system for lung cancer. Chest. 1986; 89:225S-233S. [PubMed: 3514171]

6. Pairolero PC, Williams DE, Bergstralh EJ, Piehler JM, Bernatz PE, Payne WS. Postsurgical stage I bronchogenic carcinoma: morbid implications of recurrent disease. Ann Thorac Surg. 1984; 38:331-338. [PubMed: 6091575]

7. Molina JR, Adjei AA, Jett JR. Advances in chemotherapy of non-small cell lung cancer. Chest. 2006; 130:1211-1219. [PubMed: 17035458]

8. Chemotherapy in non-small cell lung cancer: a meta-analysis using updated data on individual patients from 52 randomised clinical trials. Non-small Cell Lung Cancer Collaborative Group. BMJ. 1995; 311:899-909. [PubMed: 7580546]

9. Harpole DH Jr, Herndon JE 2nd, Wolfe WG, Iglehart JD, Marks JR. A prognostic model of recurrence and death in stage I non-small cell lung cancer utilizing presentation, histopathology, and oncoprotein expression. Cancer Res. 1995; 55:51-56. [PubMed: 7805040]

10. Johnstone DW, Byhardt RW, Ettinger D, Scott CB. Phase III study comparing chemotherapy and radiotherapy with preoperative chemotherapy and surgical resection in patients with non-small-cell 
lung cancer with spread to mediastinal lymph nodes (N2); final report of RTOG 89-01. Radiation Therapy Oncology Group. Int J Radiat Oncol Biol Phys. 2002; 54:365-369. [PubMed: 12243809]

11. Alberg AJ, Ford JG, Samet JM. Epidemiology of lung cancer: ACCP evidence-based clinical practice guidelines (2nd edition). Chest. 2007; 132:29S-55S. [PubMed: 17873159]

12. Ohe Y, Ohashi Y, Kubota K, Tamura T, Nakagawa K, Negoro S, Nishiwaki Y, Saijo N, Ariyoshi Y, Fukuoka M. Randomized phase III study of cisplatin plus irinotecan versus carboplatin plus paclitaxel, cisplatin plus gemcitabine, and cisplatin plus vinorelbine for advanced non-small-cell lung cancer: Four-Arm Cooperative Study in Japan. Ann Oncol. 2007; 18:317-323. [PubMed: 17079694]

13. Fossella FV, DeVore R, Kerr RN, Crawford J, Natale RR, Dunphy F, Kalman L, Miller V, Lee JS, Moore M, Gandara D, Karp D, Vokes E, Kris M, Kim Y, Gamza F, Hammershaimb L.

Randomized phase III trial of docetaxel versus vinorelbine or ifosfamide in patients with advanced non-small-cell lung cancer previously treated with platinum-containing chemotherapy regimens. The TAX 320 Non-Small Cell Lung Cancer Study Group. J Clin Oncol. 2000; 18:2354-2362. [PubMed: 10856094]

14. Shepherd FA, Dancey J, Ramlau R, Mattson K, Gralla R, O'Rourke M, Levitan N, Gressot L, Vincent M, Burkes R, Coughlin S, Kim Y, Berille J. Prospective randomized trial of docetaxel versus best supportive care in patients with non-small-cell lung cancer previously treated with platinum-based chemotherapy. J Clin Oncol. 2000; 18:2095-2103. [PubMed: 10811675]

15. Joss RA, Alberto P, Obrecht JP, Barrelet L, Holdener EE, Siegenthaler P, Goldhirsch A, Mermillod B, Cavalli F. Combination chemotherapy for non-small cell lung cancer with doxorubicin and mitomycin or cisplatin and etoposide. Cancer Treat Rep. 1984; 68:1079-1084. [PubMed: 6090014]

16. Koukourakis MI, Romanidis K, Froudarakis M, Kyrgias G, Koukourakis GV, Retalis G, Bahlitzanakis N. Concurrent administration of Docetaxel and Stealth liposomal doxorubicin with radiotherapy in non-small cell lung cancer : excellent tolerance using subcutaneous amifostine for cytoprotection. Br J Cancer. 2002; 87:385-392. [PubMed: 12177774]

17. A randomized trial of postoperative adjuvant chemotherapy in non-small cell lung cancer (the second cooperative study). The Study Group of Adjuvant Chemotherapy for Lung Cancer (Chubu, Japan). Eur J Surg Oncol. 1995; 21:69-77. [PubMed: 7851558]

18. Octavia Y, Tocchetti CG, Gabrielson KL, Janssens S, Crijns HJ, Moens AL. Doxorubicin-induced cardiomyopathy: from molecular mechanisms to therapeutic strategies. J Mol Cell Cardiol. 2012; 52:1213-1225. [PubMed: 22465037]

19. Peng X, Chen B, Lim CC, Sawyer DB. The cardiotoxicology of anthracycline chemotherapeutics: translating molecular mechanism into preventative medicine. Mol Interv. 2005; 5:163-171. [PubMed: 15994456]

20. Torchilin VP. Recent advances with liposomes as pharmaceutical carriers. Nat Rev Drug Discov. 2005; 4:145-160. [PubMed: 15688077]

21. Torchilin VP. Passive and active drug targeting: drug delivery to tumors as an example. Handb Exp Pharmacol. 2010:3-53. [PubMed: 20217525]

22. Torchilin VP. Recent approaches to intracellular delivery of drugs and DNA and organelle targeting. Annu Rev Biomed Eng. 2006; 8:343-375. [PubMed: 16834560]

23. Barenholz Y. Doxil® — The first FDA-approved nano-drug: Lessons learned. Journal of Controlled Release. 2012; 160:117-134. [PubMed: 22484195]

24. Biswas S, Dodwadkar NS, Sawant RR, Koshkaryev A, Torchilin VP. Surface modification of liposomes with rhodamine-123-conjugated polymer results in enhanced mitochondrial targeting. J Drug Target. 2011; 19:552-561. [PubMed: 21348804]

25. Biswas S, Dodwadkar NS, Deshpande PP, Torchilin VP. Liposomes loaded with paclitaxel and modified with novel triphenylphosphonium-PEG-PE conjugate possess low toxicity, target mitochondria and demonstrate enhanced antitumor effects in vitro and in vivo. J Control Release. 2012; 159:393-402. [PubMed: 22286008]

26. Biswas S, Dodwadkar NS, Piroyan A, Torchilin VP. Surface conjugation of triphenylphosphonium to target poly(amidoamine) dendrimers to mitochondria. Biomaterials. 2012; 33:4773-4782.

[PubMed: 22469294] 
27. Gupta B, Levchenko TS, Torchilin VP. Intracellular delivery of large molecules and small particles by cell-penetrating proteins and peptides. Adv Drug Deliv Rev. 2005; 57:637-651. [PubMed: 15722168]

28. Torchilin VP. Tat peptide-mediated intracellular delivery of pharmaceutical nanocarriers. Adv Drug Deliv Rev. 2008; 60:548-558. [PubMed: 18053612]

29. Torchilin VP. Cell penetrating peptide-modified pharmaceutical nanocarriers for intracellular drug and gene delivery. Biopolymers. 2008; 90:604-610. [PubMed: 18381624]

30. Sawant R, Torchilin V. Intracellular transduction using cell-penetrating peptides. Mol Biosyst. 2010; 6:628-640. [PubMed: 20237640]

31. Koshkaryev A, Piroyan A, Torchilin VP. Bleomycin in octaarginine-modified fusogenic liposomes results in improved tumor growth inhibition. Cancer Letters. 2012 http://dx.doi.org/10.1016/ j.canlet.2012.06.008.

32. Khalil IA, Kogure K, Futaki S, Hama S, Akita H, Ueno M, Kishida H, Kudoh M, Mishina Y, Kataoka K, Yamada M, Harashima H. Octaarginine-modified multifunctional envelope-type nanoparticles for gene delivery. Gene Ther. 2007; 14:682-689. [PubMed: 17268535]

33. Zhang C, Tang N, Liu X, Liang W, Xu W, Torchilin VP. siRNA-containing liposomes modified with polyarginine effectively silence the targeted gene. J Control Release. 2006; 112:229-239. [PubMed: 16545478]

34. Furukawa R, Yamada Y, Takenaga M, Igarashi R, Harashima H. Octaarginine-modified liposomes enhance the anti-oxidant effect of Lecithinized superoxide dismutase by increasing its cellular uptake. Biochem Biophys Res Commun. 2011; 404:796-801. [PubMed: 21168389]

35. Khalil IA, Kogure K, Futaki S, Harashima H. High density of octaarginine stimulates macropinocytosis leading to efficient intracellular trafficking for gene expression. J Biol Chem. 2006; 281:3544-3551. [PubMed: 16326716]

36. Torchilin VP, Levchenko TS, Lukyanov AN, Khaw BA, Klibanov AL, Rammohan R, Samokhin GP, Whiteman KR. p-Nitrophenylcarbonyl-PEG-PE-liposomes: fast and simple attachment of specific ligands, including monoclonal antibodies, to distal ends of PEG chains via pnitrophenylcarbonyl groups. Biochim Biophys Acta. 2001; 1511:397-411. [PubMed: 11286983]

37. Allen TM, Sapra P, Moase E. Use of the post-insertion method for the formation of ligand-coupled liposomes. Cell Mol Biol Lett. 2002; 7:889-894. [PubMed: 12378272]

38. Ishida T, Iden DL, Allen TM. A combinatorial approach to producing sterically stabilized (Stealth) immunoliposomal drugs. FEBS Lett. 1999; 460:129-133. [PubMed: 10571074]

39. Koren E, Apte A, Jani A, Torchilin VP. Multifunctional PEGylated 2C5-immunoliposomes containing $\mathrm{pH}$-sensitive bonds and TAT peptide for enhanced tumor cell internalization and cytotoxicity. Journal of Controlled Release. 2012; 160:264-273. [PubMed: 22182771]

40. Yang TM, Barbone D, Fennell DA, Broaddus VC. Bcl-2 family proteins contribute to apoptotic resistance in lung cancer multicellular spheroids. Am J Respir Cell Mol Biol. 2009; 41:14-23. [PubMed: 19097992]

41. Perche F, Torchilin VP. Cancer cell spheroids as a model to evaluate chemotherapy protocols. Cancer Biol Ther. 2012; 13

42. Schiller JH, Harrington D, Belani CP, Langer C, Sandler A, Krook J, Zhu J, Johnson DH. Comparison of four chemotherapy regimens for advanced non-small-cell lung cancer. N Engl J Med. 2002; 346:92-98. [PubMed: 11784875]

43. Otterson GA, Villalona-Calero MA, Hicks W, Pan X, Ellerton JA, Gettinger SN, Murren JR. Phase I/II study of inhaled doxorubicin combined with platinum-based therapy for advanced non-small cell lung cancer. Clin Cancer Res. 2010; 16:2466-2473. [PubMed: 20371682]

44. Seymour LW, Ferry DR, Kerr DJ, Rea D, Whitlock M, Poyner R, Boivin C, Hesslewood S, Twelves C, Blackie R, Schatzlein A, Jodrell D, Bissett D, Calvert H, Lind M, Robbins A, Burtles S, Duncan R, Cassidy J. Phase II studies of polymer-doxorubicin (PK1, FCE28068) in the treatment of breast, lung and colorectal cancer. Int J Oncol. 2009; 34:1629-1636. [PubMed: 19424581]

45. Tsoutsou PG, Froudarakis ME, Bouros D, Koukourakis MI. Hypofractionated/accelerated radiotherapy with cytoprotection (HypoARC) combined with vinorelbine and liposomal 
doxorubicin for locally advanced non-small cell lung cancer (NSCLC). Anticancer Res. 2008; 28:1349-1354. [PubMed: 18505077]

46. Weiss RB. The anthracyclines: will we ever find a better doxorubicin? Semin Oncol. 1992; 19:670-686. [PubMed: 1462166]

47. Gabizon A, Shmeeda H, Barenholz Y. Pharmacokinetics of pegylated liposomal Doxorubicin: review of animal and human studies. Clin Pharmacokinet. 2003; 42:419-436. [PubMed: 12739982]

48. Gabizon A, Catane R, Uziely B, Kaufman B, Safra T, Cohen R, Martin F, Huang A, Barenholz Y. Prolonged circulation time and enhanced accumulation in malignant exudates of doxorubicin encapsulated in polyethylene-glycol coated liposomes. Cancer Res. 1994; 54:987-992. [PubMed: 8313389]

49. Fretz MM, Penning NA, Al-Taei S, Futaki S, Takeuchi T, Nakase I, Storm G, Jones AT. Temperature-, concentration- and cholesterol-dependent translocation of L- and D-octa-arginine across the plasma and nuclear membrane of CD34+ leukaemia cells. Biochem J. 2007; 403:335342. [PubMed: 17217340]

50. Abbott A. Cell culture: biology's new dimension. Nature. 2003; 424:870-872. [PubMed: 12931155]

51. Friedrich J, Seidel C, Ebner R, Kunz-Schughart LA. Spheroid-based drug screen: considerations and practical approach. Nat Protoc. 2009; 4:309-324. [PubMed: 19214182]

52. Hirschhaeuser F, Menne H, Dittfeld C, West J, Mueller-Klieser W, Kunz-Schughart LA. Multicellular tumor spheroids: an underestimated tool is catching up again. J Biotechnol. 2010; 148:3-15. [PubMed: 20097238]

53. Yamada KM, Cukierman E. Modeling tissue morphogenesis and cancer in 3D. Cell. 2007; 130:601-610. [PubMed: 17719539]

54. Friedrich J, Eder W, Castaneda J, Doss M, Huber E, Ebner R, Kunz-Schughart LA. A reliable tool to determine cell viability in complex 3-d culture: the acid phosphatase assay. J Biomol Screen. 2007; 12:925-937. [PubMed: 17942785]

55. Kunz-Schughart LA, Freyer JP, Hofstaedter F, Ebner R. The use of 3-D cultures for highthroughput screening: the multicellular spheroid model. J Biomol Screen. 2004; 9:273-285. [PubMed: 15191644]

56. Mueller-Klieser W. Tumor biology and experimental therapeutics. Crit Rev Oncol Hematol. 2000; 36:123-139. [PubMed: 11033302] 
A
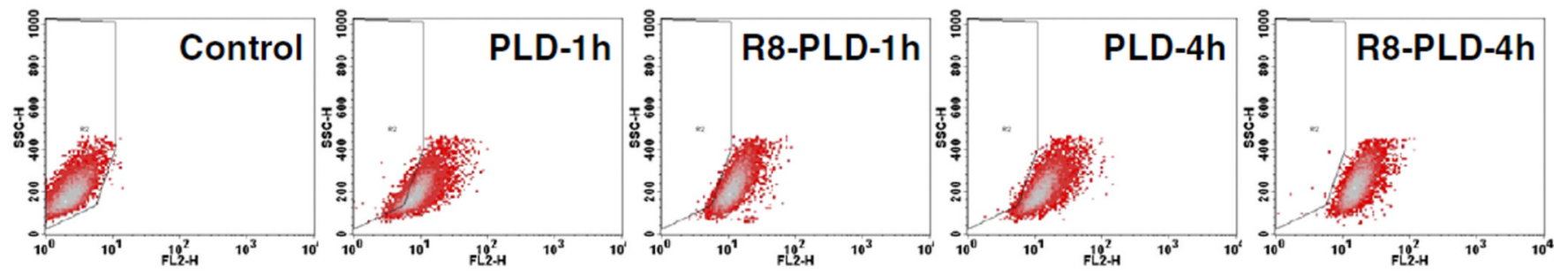

B
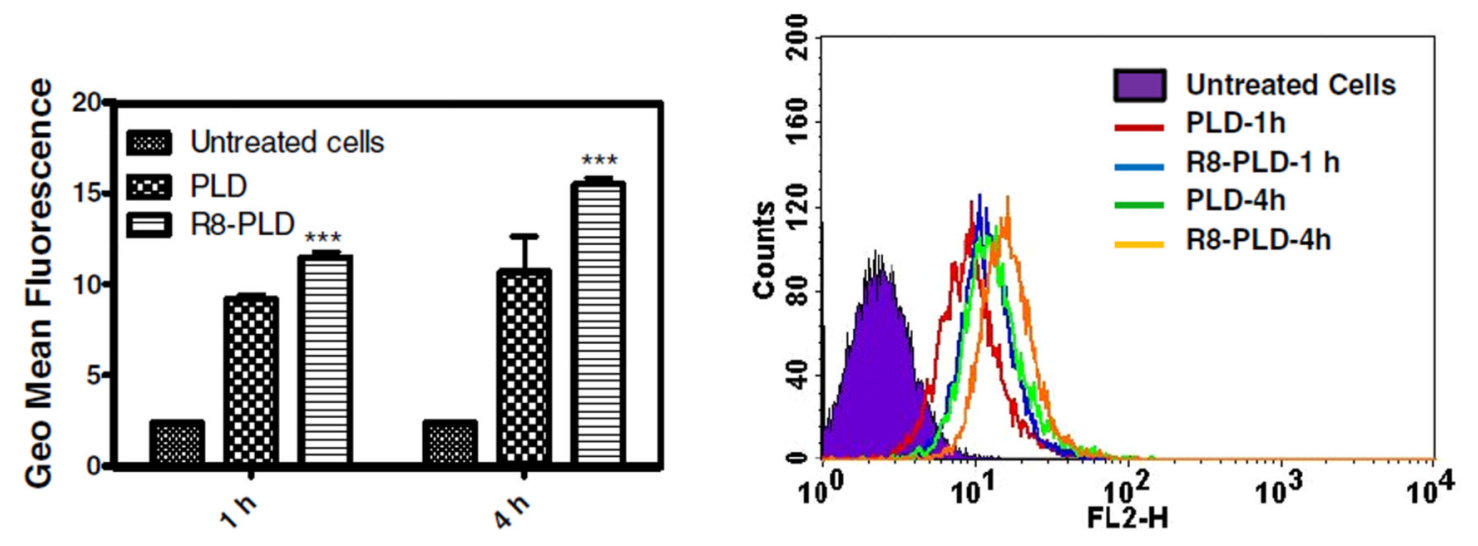

Figure 1.

Comparison of cellular uptake of R8-modified and unmodified PEGylated liposomal doxorubicin by flow cytometry. The A549 cells were incubated with PLD and R8-PLD at 6 $\mu \mathrm{g} / \mathrm{mL}$ of Dox for 1 and $4 \mathrm{~h}$, after which the FACS analysis was performed. The cellassociated Dox fluorescence was measured. (A) Representative dot plot obtained from FACS analysis showing the cell population labeled with Dox after incubation with PLD or R8-PLD at $1 \mathrm{~h}$ and $4 \mathrm{~h}$ time points. (B) Comparison of the geometric mean of fluorescence of the cells treated with PLD or R8-PLD (left panel) and the representative histogram plot obtained from histogram statistics of the FACS analysis (right panel). The data are mean \pm SD, averaged from three separate experiments. The significance of difference between the mean was analyzed by Student's t-test, $* * *$ indicates $p<0.001$. 
A

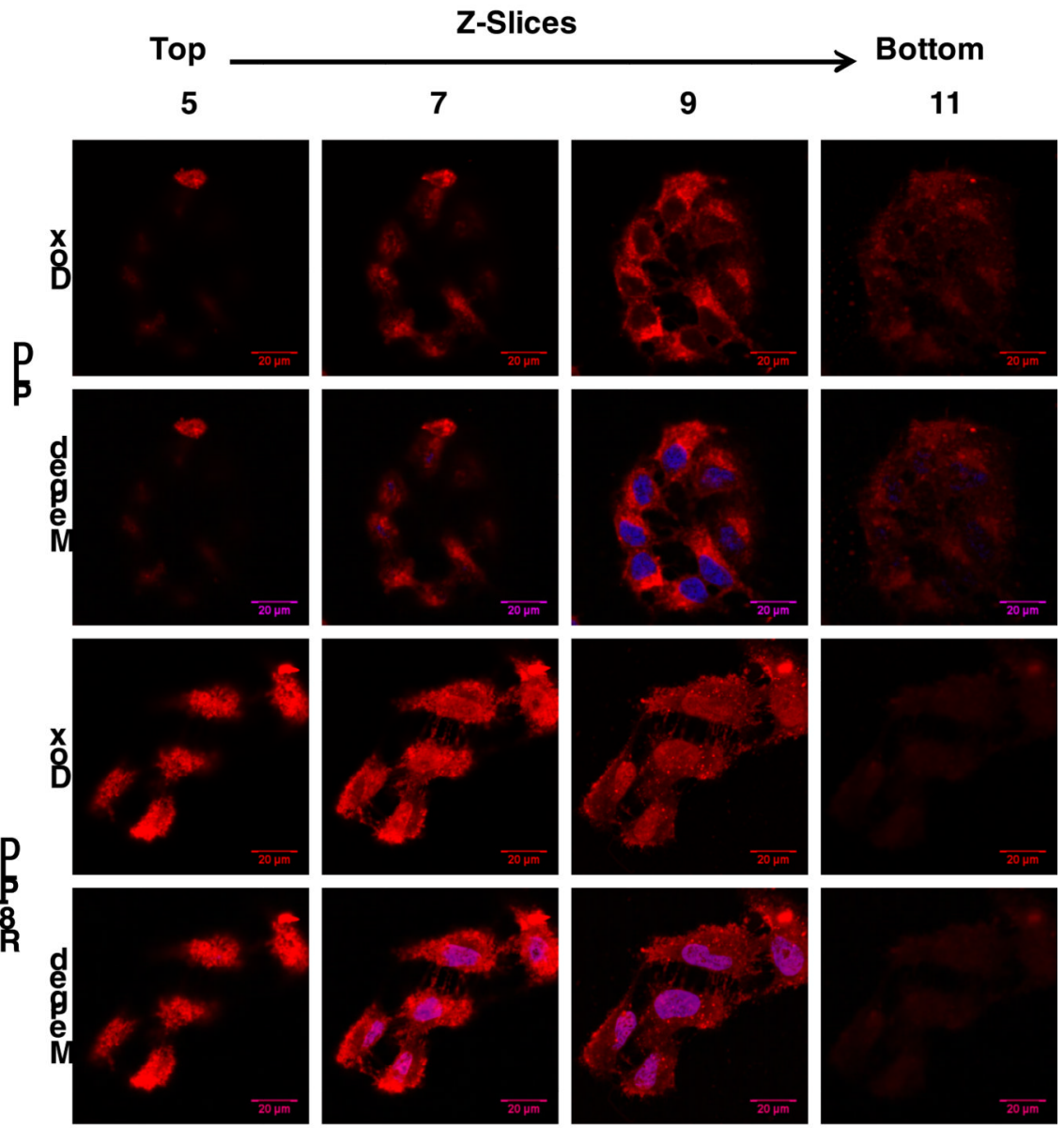

B

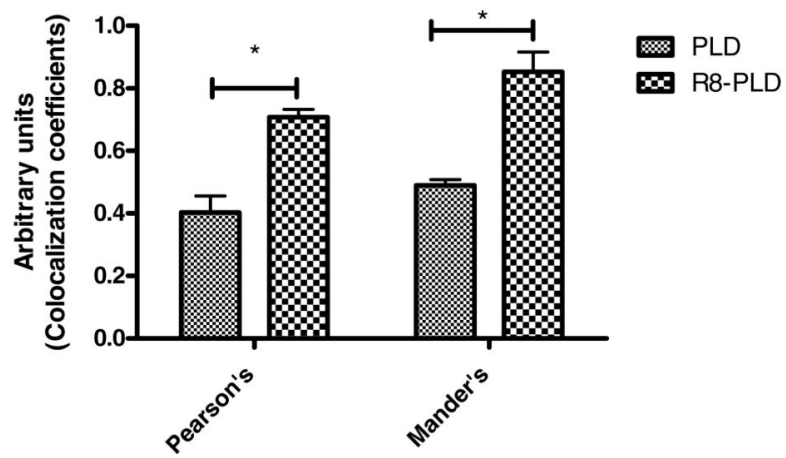

Figure 2.

Assessment of cellular internalization by confocal microscopy. (A) Confocal laser scanning micrographs of A549 cells obtained from z-experiment. A549 cells were incubated with PLD or R8-PLD for 90 min, were taken at a fixed XY plane along a consecutive Z-axes (Z-5, 7, 9, 11 from total 16 slices). The nuclei were stained with Hoechst 33342. The lower panel represents merged pictures of Dox and Hoechst 33342 fluorescence. Scale bar: $20 \mu \mathrm{m}$. (B) Assessment of nuclear localization of Doxorubicin delivered by PLD and R8-PLD. The merged (nuclei stained and PLD/R8-PLD treated) pictures of the center z-slices were analyzed with Image $J$ software and the colocalization coefficients were obtained. The data 
are mean $\pm \mathrm{SD}$, averaged from 3 images of the same treatment. *, $p<0.05$, paired Student's ttest. 
A

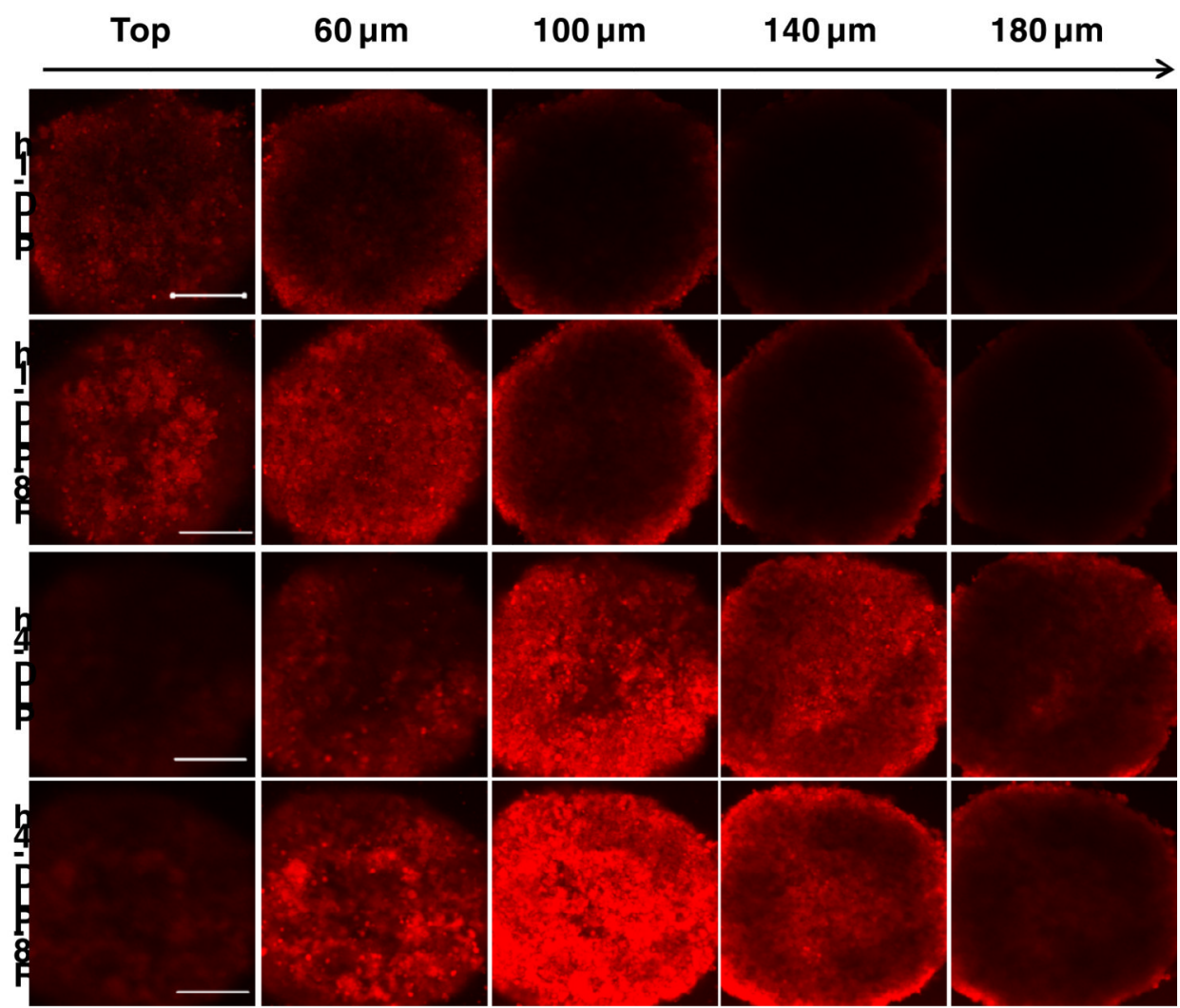

B

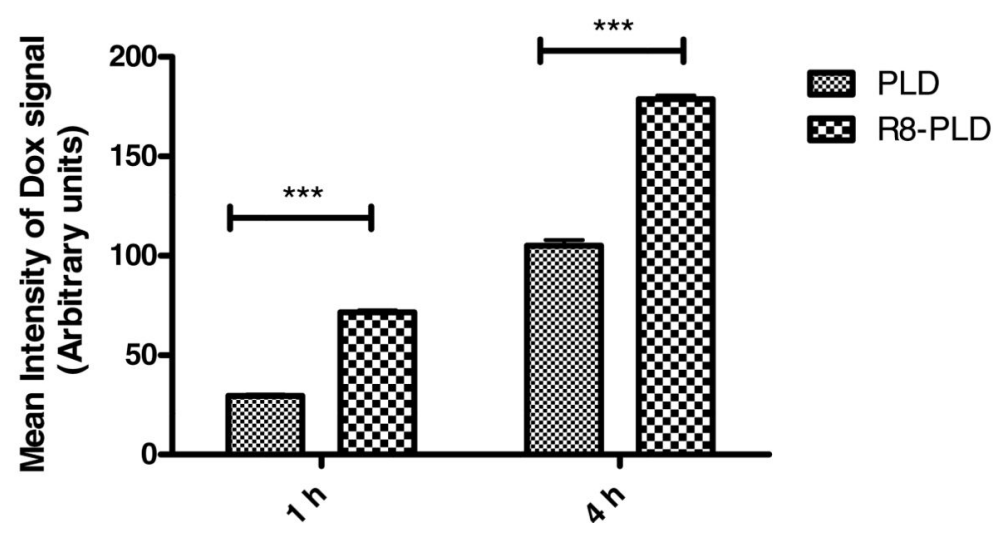

Figure 3.

Accumulation of PLD and R8-PLD in A549 spheroids by confocal laser scanning microscopy. (A) Selected Z-stacked micrographs of A549 spheroids, taken at consecutive Zaxes were shown. (B) Graphical representation of mean intensity of the Doxorubicin signal of the center slice (100 $\mu \mathrm{m}$ inside from top) of PLD and R8-PLD dosed spheroids quantified with Image $J$ software. The cells were treated with PLD and R8-PLD at $100 \mu \mathrm{M}$ of Dox for 1 and $4 \mathrm{~h}$. Images were selected out of 16 Z-slices. Scale bar: $200 \mu \mathrm{m}$. The data in figure B are mean $\pm \mathrm{SD}$, averaged from 9 different regions of interest from the images of two spheroids. ***, $p<0.001$, paired Student's t-test. 
A
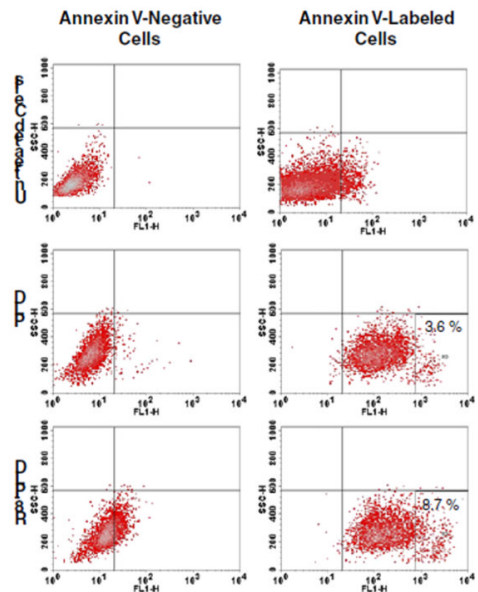

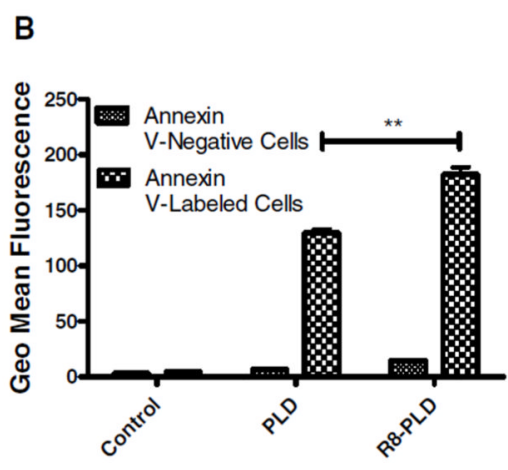

C

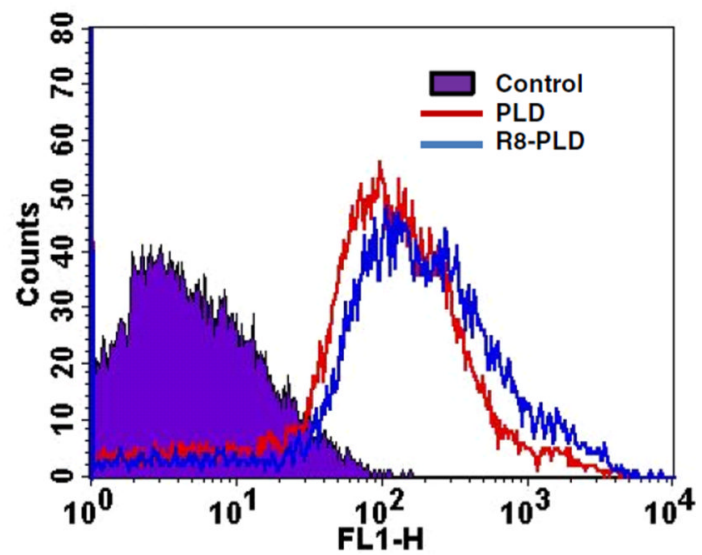

Figure 4.

Comparison of up-regulation of an early apoptotic marker, phosphatidyl serine, upon treatment with PLD and R8-PLD by flow cytometry. The A549 cells were treated with PLD or R8-PLD at $30 \mu \mathrm{g} / \mathrm{mL}$ of Dox for $4 \mathrm{~h}$, then incubated for $18 \mathrm{~h}$ in complete media. The cells were treated with Annexin V-Alexa Fluor 488 conjugate, the ligand of phosphatidyl serine. The phosphatidyl serine receptor translocates from cytoplasm to the outer cell surface on the initiation of apoptosis. The labeling of cells with Annexin V-Alexa Fluor 488 conjugate was measured by FACS analysis. (A) Representative dot plot showing the cell population with or without Annexin V labeling. (B) Geometric mean of fluorescence of PLD/R8-PLD dosed cells treated with or without Annexin V Alexa Fluor 488 conjugate, and (C) Representative histogram plot of cells treated with PLD or R8-PLD followed by Annexin V-Alexa 488.

Data in (B) are mean $\pm \mathrm{SD}$, averaged from three separate experiments. ** indicates $p<0.01$, analyzed by the paired Student's t-test. 

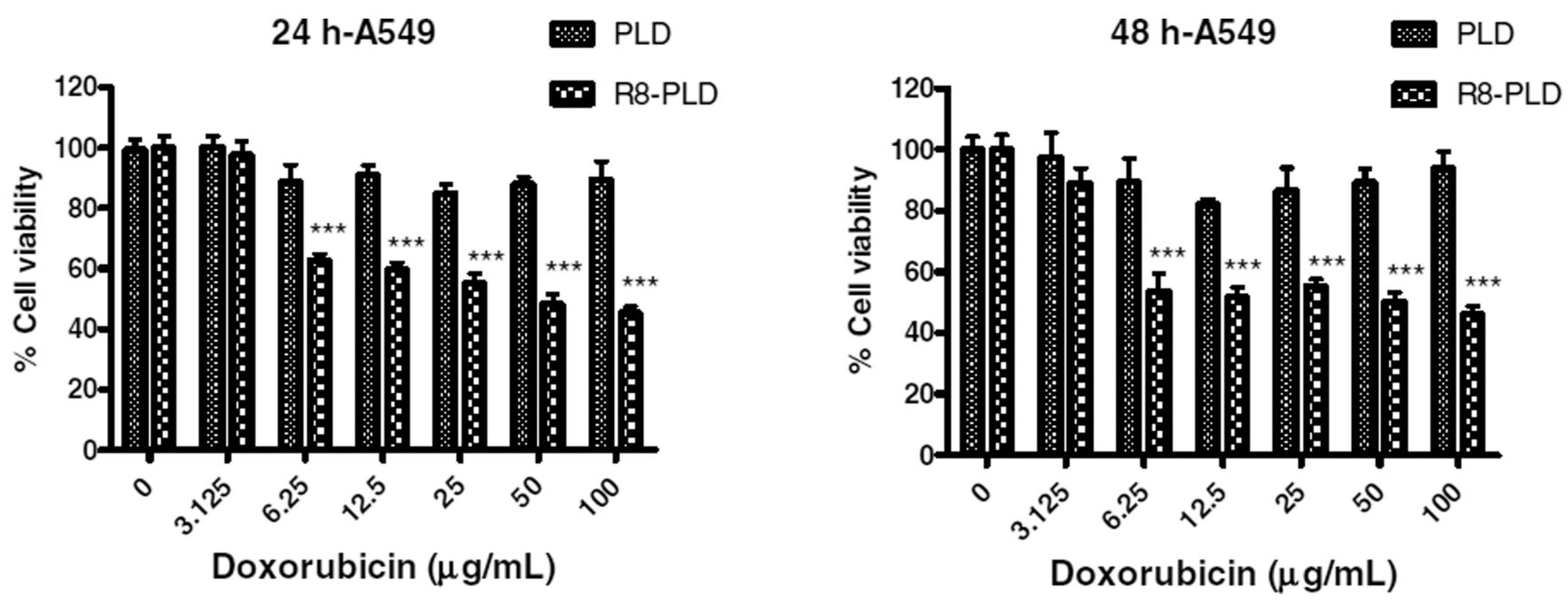

Figure 5.

Assessment of Dox-induced cell death of A549 cells treated with PLD and R8-PLD. Cells were incubated with PLD or R8-PLD at a Dox concentration of 0 to $100 \mu \mathrm{g} / \mathrm{mL}$ for $4 \mathrm{~h}$ followed by the incubation period of 24 and $48 \mathrm{~h}$ before cell viability was measured. The data are mean $\pm \mathrm{SD}$, averaged from three separate experiments. ${ }^{* * *}, p<0.001$, paired Student's t-test. 
A

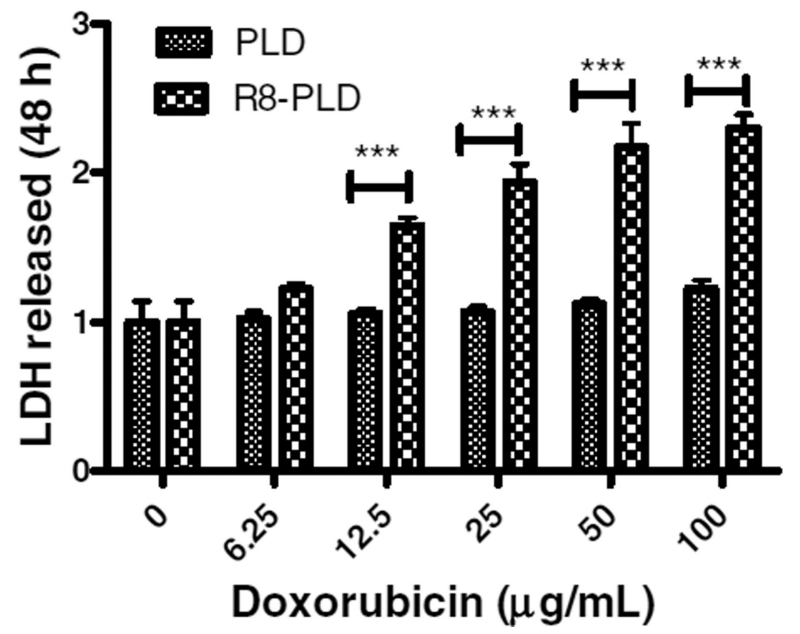

B

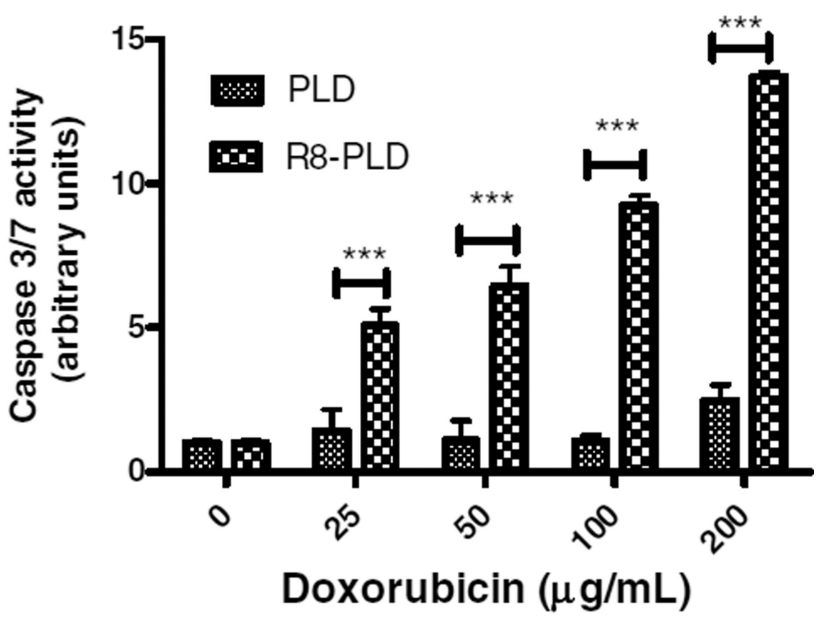

Figure 6.

The effect of PLD and R8-PLD on Dox-induced LDH release (A) and caspase 3/7 activity (B) in A549 cells. The cells were treated with PLD or R8-PLD at varied Dox concentration for $4 \mathrm{~h}$, media removed and cells incubated for $48 \mathrm{~h}$ in complete media before analyzing the media for LDH release and the cell lysate for caspase 3/7 activity. Each bar represents mean $\pm \mathrm{SD}$ of $\mathrm{n}=3$ from 3 separate experiments. The significance of differences between the means was analyzed by the paired Student's t-test. ***indicates $p<0.001$. 
A

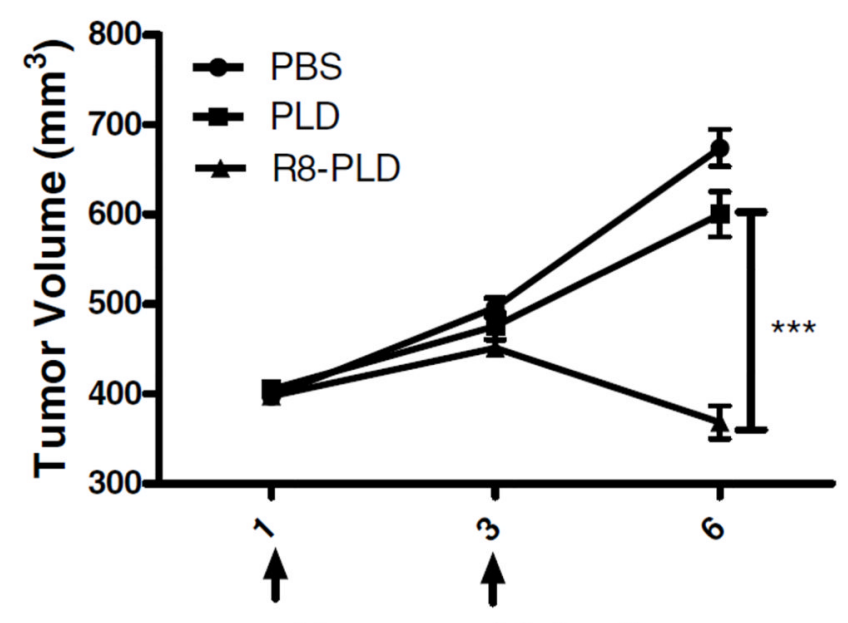

Days post-injection

B

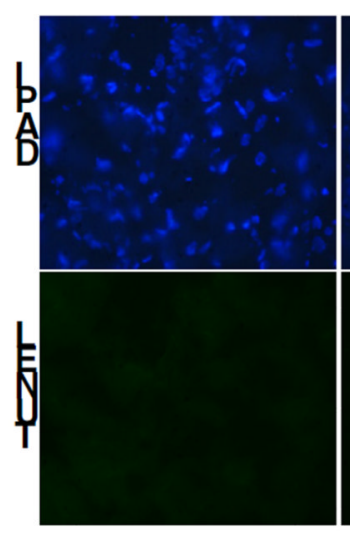

PLD

R8-PLD
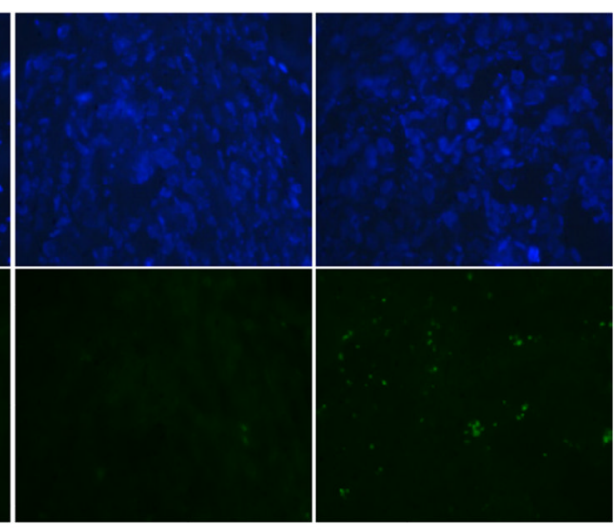

Figure 7. unpaired Student's t test. *** indicates $p<0.001$ compared to PBS.

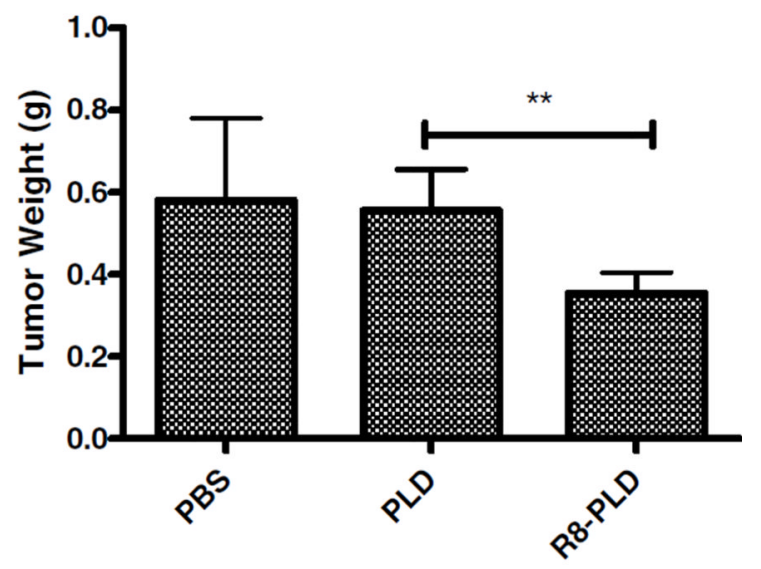

C

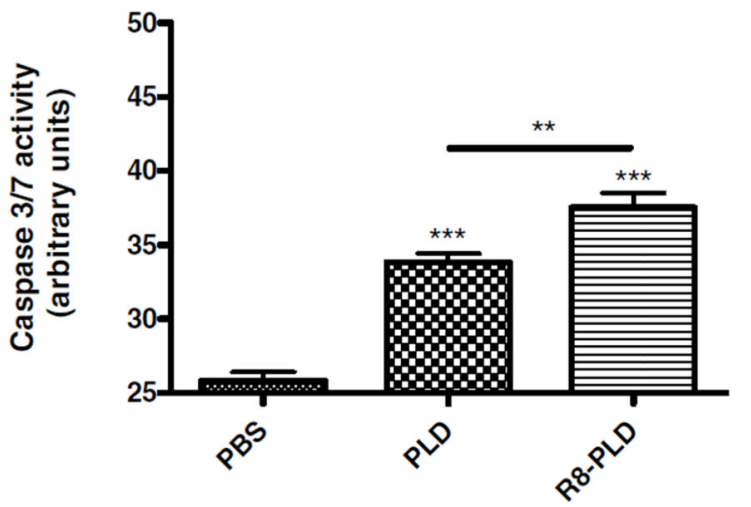

Assessment of the in vivo therapeutic efficacy of R8-modified PLD compared to unmodified PLD i.v. in A549-tumor xenograft. (A) Tumor volume and weight (arrows indicate treatment). (B) Apoptosis analysis. Apoptotic cells were detected in frozen tumor sections, determined by TUNEL assay and visualized by fluorescence microscopy. The upper panel shows the sections stained with Hoechst 33342 and the right panel shows the TUNEL staining. Magnifications-20X objectives. (C) Measurement of caspase 3/7 level in A549 tumor. The tumors isolated from the treatment groups of PBS, PLD or R8-PLD were homogenized, centrifuged and a tumor lysate equivalent to $25 \mu \mathrm{g}$ of proteins was analyzed using the Apo-ONE Homogeneous Caspase 3/7 Assay kit. ** and ***, $\mathrm{P}<0.01$ and 0.001, 